Carrier Mediated like Uptake of Salicylic Acid by Liposomes

O高木優憲 ${ }^{1)}$ 、山下伸二 ${ }^{1)}$ 、多喜陽子 1)、坂根稔康 ${ }^{1)}$ 、瀬崎 仁 1)、灘井種一 1)、 西 正敏 1)、杉原正久 2)、奥 直人 ${ }^{3)}$

1)摂南大学薬学部、2)沢井製薬大阪研、3)静岡県立大学薬学部

\title{
TRANSPORT MECHANISMS OF MONOCARBOXYLIC ACID DRUGS THROUGH THE LIPID BILAYER
}

\author{
Masanori TAKAGI $^{1)}$, Shinji YAMASHITA ${ }^{1)}$, Yoko TAKI'), Toshiyasu SAKANE'), \\ Hitoshi SEZAKI ${ }^{1)}$, Tanekazu NADAI ${ }^{1)}$, Masatoshi NISHI ${ }^{1)}$, \\ Masahisa SUGIHARA ${ }^{2)}$ and Naoto OKU ${ }^{3)}$
}

1) Faculty of Pharmaceutical Sciences, Setsunan University, Hirakata, Osaka 520

2) Osaka Research Laboratory, Sawai Pharmaceutical Co., LTD. Asahi-ku, Osaka 535

3) School of Pharmaceutical Sciences, University of Shizuoka, Yada, Shizuoka 422

【目的】サリチル酸などのモノカルボン酸系薬物は、 消化管内の生理学的 $\mathrm{pH}$ においてほほ完全に解離 しているにもかかわらず、経口投与後、極めて速や かに吸収されることが知られている。近年、小腸上 皮細胞にモノカルボン酸輸送担体の存在が明らか にされ、これらの薬物の吸収に関与している可能性 が指摘されている 1) が、実際の消化管の吸収にお ける担体輸送系の寄与、基質認識性については未だ 明らかでない。さらに、この様な特殊輸送系を介し て生体異物である薬物を意図して体内に取り込む ことの合目性についても、疑問な点が多く残されて いる。一方我々は、輸送タンパクを含まない単純な 脂質膜で構成されたリポソームにおけるこれら薬 物の取り込みに、オーバーシュート現象など、あた かも担体輸送されているかの様な現象が観察され ることを見出し、物理化学的側面から新たな膜透過 機構を提唱してきた。今回、各薬物の脂質膜透過機 構に関してより詳細な検討を行うとともに、実際の 消化管吸収における担体介在性、及び非介在性輸送 の寄与を明らかにすることを目的として種々の検 討を行った。さらに、サリチル酸、安息香酸などが それ自体脂質膜に対して高い透過性を示すこと、及 び各薬物間で膜透過性に違いが観察される理由を 物理化学的に説明するため、薬物の分子構造に基づ いた透過性の解析を行った。

【実験方法】リポソームとして、 egg$\mathrm{PC}$ : Cholesterol =1:1 の組成を持つ MLVを常法に 従って調製した。MLVへの ${ }^{14} \mathrm{C}$-サリチル酸 $\left({ }^{14} \mathrm{C}\right.$ -
$\mathrm{SA}, 10 \mu \mathrm{M})$ の取り込み速度は、通常の小腸 BBMVs での取り込み実験と同様の迅速ろ過法によって測 定した。他の薬物のリポソーム膜透過性は、 ${ }^{14} \mathrm{C}-\mathrm{SA}$ の取り込みに対する阻害効果を指標として評価し た。また、in vivo、in vitroにおける消化管吸収速 度は、それぞれラット小腸を用いた単回潅流法、及 びTranswell 上に培養した Caco-2 単層膜を用いて 算出し、リポソーム膜透過性との相関性を検討した。 薬物の分子構造の解析には、CAChe（ソニー・テ クトロニクス)を用い分子全体及び極性基部分の表 面積を算出した。

【結果及び考察】 ${ }^{14} C-S A$ のリポソーム内取り込み 機構: リポソーム内 $\mathrm{pH}$ を 7.5 、外側を 5.8 として 内向きのプロトン勾配を付加した場合、 ${ }^{14} \mathrm{C}-\mathrm{SA} の$ 取り込み初速度は極めて速く、明らかなオーバーシ ユート現象が認められた。一方、プロトン勾配非存 在下では、取り込みはほとんど見られなかった。ま た、 $1 \mathrm{mM}$ の安息香酸をリポソーム外液中に添加し た場合、 ${ }^{14} \mathrm{C}-\mathrm{SA}$ の取り込みは顕著に抑制され、構 造類似化合物による阻害を受けることが示された (Fig.1)。さらに ${ }^{14} \mathrm{C}-\mathrm{SA}$ の初期取り込み速度は、 (1)リポソーム外 $\mathrm{pH}$ の上昇に従って低下し、リポ ソーム膜内外でのプロトン勾配に依存することが 確認された、(2) 外液中に非標識サリチル酸を添加 した場合、濃度の上昇に伴った明らかな飽和現象が 認められた、(3) 低温下 $\left(4^{\circ} \mathrm{C}\right)$ において有意な低下 が観察された。以上の結果は小腸 BBMVs による 取り込み特性とほほ同様であり、これまで担体介在 
性輸送を表すと考えられてきた現象が、サリチル酸 の極めて速やかな膜透過を仮定することによって、 物理化学的に説明し得ることが明らかとなった。 消化管膜透過性との相関性：各薬物 $1 \mathrm{mM}$ をリポ ソーム外液に添加し、 ${ }^{14} \mathrm{C}-\mathrm{SA} の$ 初期取り込みに対 する阻害効果より、それぞれの膜透過性を評価した。 非標識サリチル酸、安息香酸及びバルプロ酸は極め て高い阻害を示し、またサリチル酸の構造異性体で ある $\mathrm{p}$ ヒヒドロキシ、m-ヒドロキシ安息香酸による 阻害効果には有意な差が認められた。各薬物の阻害 率と、単回潅流法により求めたラット小腸膜透過性 (Fig.2)、及び Caco-2 単層膜透過性との間には良好 な相関性が認められたことより、今回我々が提唱し た機構が、実際の消化管吸収においても大きく寄与 している可能性が示された。 分子構造解析による膜透過性の評価：Palm らは、 薬物の分子構造解析によって得られる種々パラメ ー夕のうち、極性部分の表面積(Polar Surface Area）の大きさが膜透過性を決定する重要な要因 であることを報告している2)。今回用いた各薬物に ついて、分子力学法を用いて MM2 力場における構 造最適化を行い、Polar Surface Area を算出した 結果、ラット小腸膜透過性との間にある程度の相関 が得られたものの、このパラメータのみでは充分な 評価が困難であると考えられた。そこで、極性基の 強さを表すパラメータとして、分子軌道法を用いて 等静電ポテンシャル表面積を算出した。負のポテン シャル表面積の割合 (ESP ratio)を新しいパラメー タとして、Polar Surface Area との重回帰分析を 行ったところ、各薬物の膜透過性を精度良く予測し 得ることが明らかとなった (Fig.3)。これは、サリ チル酸や安息香酸が分子構造的に極めて高い脂質 膜透過性を有していることを意味しており、我々の 提唱した膜透過機構を裹付ける結果と考えられた。

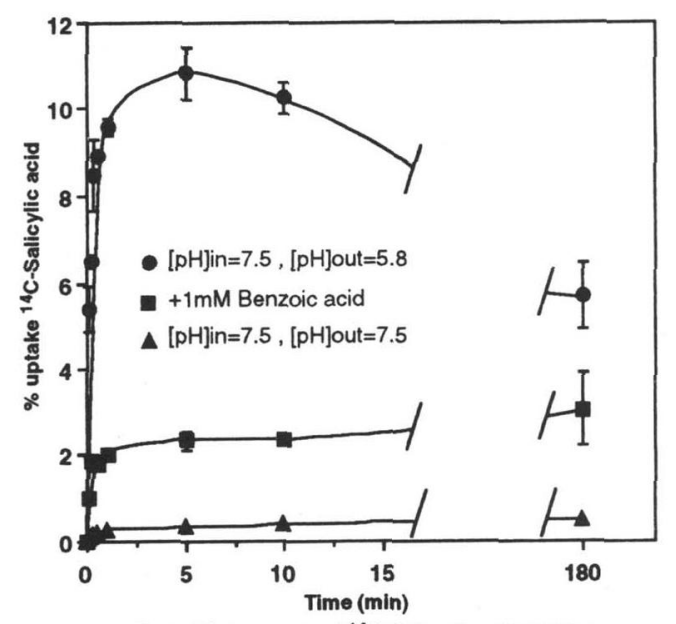

Fig.1 Time course of ${ }^{14} \mathrm{C}$-Salicylle acid uptake

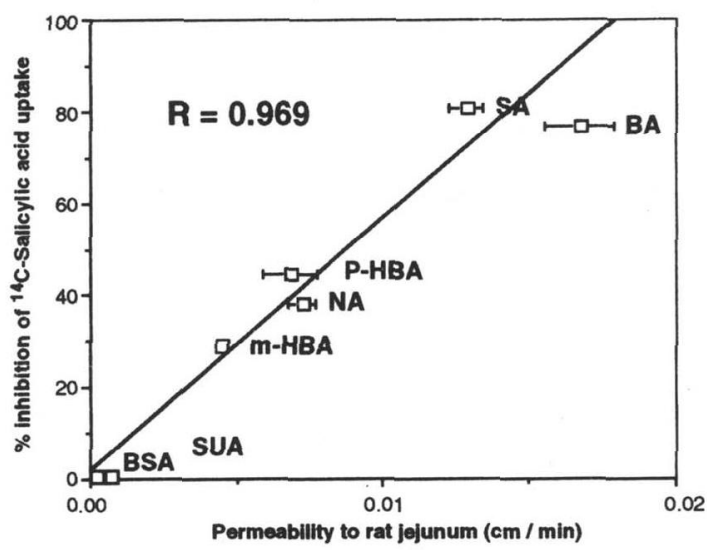

Fig.2 Relationship between inhibitory effect of drugs on liposomal uptake of ${ }^{14} \mathrm{C}$-salicylate and their permeability to rat jejunum Salicylic acid(SA), Benzoic acid(BA), p-Hydroxybenzoic acid(pHBA), Nicotinic acid(NA),
m-Hydroxybenzoic acid(m-HBA), Sulfanilic acid(SUA), Benzenesulfonic acid(BSA),

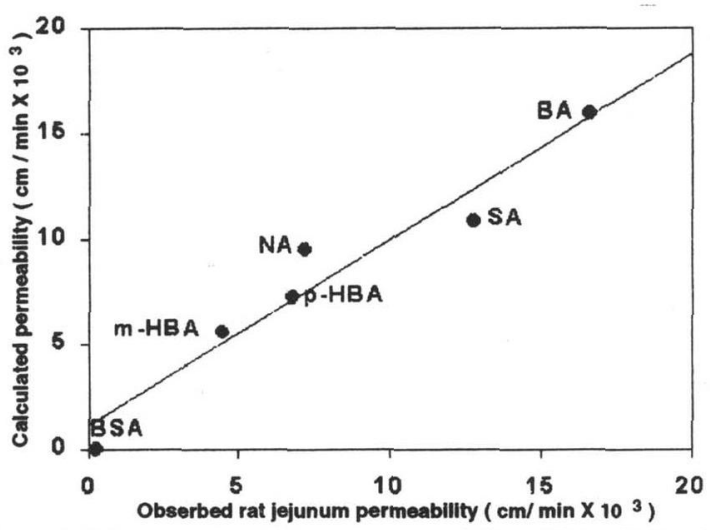

Fig.3 Multiple regression of rat jejunum permeability on PSA and ESP ratio

[ABSTRACT] In this report, we have determined the uptake of salicylic acid (SA) by liposomes and proposed the $\mathrm{pH}$-dependent but not carrier-mediated transport mechanisms of SA through the lipid bilayer. The permeability of various drugs to the liposomal membrane, estimated from their inhibitory effects on SA uptake, correlated well with their permeability to rat intestinal membrane in vivo, and that to Caco-2 monolayer in vitro. In addition, the high permeability of SA or benzoic acid to the lipid bilayer was confirmed by means of molecular mechanics calculations in which the polar surface area and the electrical potential of drug molecules were used as the parameters of their permeability. Our results could be expected to describe the mechanisms of the intestinal absorption of monocarboxylic acid drugs.

[REFERENCES] 1) Tsuji A. and Tamai I., Pharm. Res., 13, 963-977 (1996).

2) Palm K., Luthman K., Ungell A.L., Strandlund G. and Artursson P., J. Pharm. Sci., 85, 32-39 (1996). 